\title{
Clinical utility of plecanatide in the treatment of chronic idiopathic constipation
}

This article was published in the following Dove Press journal: International Journal of General Medicine

\section{Bianca N Islam \\ Sarah K Sharman \\ Darren D Browning}

Department of Biochemistry and Molecular Biology, Medical College of Georgia, Augusta University, Augusta, GA, USA
Correspondence: Darren D Browning Department of Biochemistry and Molecular Biology, Medical College of Georgia at Augusta University, CNI I64, I4I 0 Laney Walker Blvd, Augusta, GA 30912-2100, USA

$\mathrm{Tel}+\mathrm{I} 7067219526$

Fax +I 7067216608

Email dbrowning@augusta.edu

\begin{abstract}
Constipation is an important health burden that reduces the quality of life for countless millions of people. Symptom-centric therapeutics are often used to treat constipation due to unknown etiology, but in many cases, these drugs are either inadequate or have significant side effects. More recently, synthetic peptide agonists for epithelial guanylyl cyclase $\mathrm{C}$ (GC-C) have been developed which are effective at treating constipation in a sub-population of adult constipation patients. The first to market was linaclotide that is structurally related to the diarrheagenic enterotoxin, but this was followed by plecanatide, which more closely resembles endogenous uroguanylin. Both the drugs exhibit almost identical clinical efficacy in about $20 \%$ of patients, with diarrhea being a common side effect. Despite the potential for reduced side effects with plecanatide, detailed analysis suggests that clinically, they are very similar. Ongoing clinical and preclinical studies with these drugs suggest that treating constipation might be the tip of the iceberg in terms of clinical utility. The expression of cGMP signaling components could be diagnostic for functional bowel disorders, and increasing cGMP using GC-C agonists or phosphodiesterase inhibitors has huge potential for treating enteric pain, ulcerative colitis, and for the chemoprevention of colorectal cancer.
\end{abstract}

Keywords: linaclotide, irritable bowel syndrome, guanylyl cyclase, phosphodiesterase, cGMP, diarrhea

\section{Introduction}

Chronic constipation is one of the most common gastrointestinal complaints in the United States, affecting about $30 \%$ of Americans per year. ${ }^{1}$ While not a life-threatening condition, chronic constipation can have a profound negative effect on quality of life. Constipation is characterized by a variety of symptoms including lumpy or hard stools, infrequent bowel movements, abdominal cramping and bloating, excessive straining, and the sensation of incomplete defecation. ${ }^{2}$ Chronic constipation is often due to dietary factors (ie, poor fiber intake), lifestyle factors (ie, reduced activity and mobility), or disorders in colonic propulsion or rectal emptying. Secondary causes of chronic constipation are mediated by medications (ie, opioids, antihypertensives, tricyclic antidepressants, etc) or result from organic disease processes (ie, diabetes, colorectal cancer, polyps, strictures, etc). ${ }^{2}$

\section{Constipation disorders: chronic idiopathic constipation (CIC), irritable bowel syndrome with constipation (IBS-C), and opioid-induced constipation (OIC)}

Functional bowel disorders (FBDs) are distinguished from other gastrointestinal illnesses based on symptom duration ( $>6$ months), symptoms at current presentation 
(at least 3 months), and frequency (symptoms on average, at least 1 day/week). Constipation is associated with three of the six FBDs highlighted in the 2016 Rome IV guidelines: IBS (C1), functional constipation/CIC (C2), and OIC (C6). ${ }^{3}$ The largest group of chronic constipation sufferers largely fall under functional constipation where no identifiable structural or biochemical etiology is known to be the cause. As defined in the Rome IV guidelines, the diagnosis of functional constipation (CIC) is made when the patient's symptomatology does not meet the criteria for IBS. In the new guidelines, bloating and pain are not considered predominant symptoms of functional constipation and may not be present. The diagnosis is made when patients experience two of the following symptoms in the past 3 months: fewer than three bowel movements in a week, straining, lumpy or hard stool, abdominal symptoms such as bloating and abdominal discomfort, and sensation of incomplete defecation. ${ }^{4,5}$ The diagnosis of IBS is made when a patient experiences recurrent abdominal pain, on average, at least 1 day/week in the last 3 months, and is associated with two or more of the following criteria related to defecation, associated with a change in frequency of stool, and lastly associated with a change in form (appearance) of stool. Furthermore, to classify the IBS-C subtype, more than $25 \%$ of bowel movements are with Bristol stool form type 1 or 2 and less than $25 \%$ of bowel movements are with Bristol stool form type 6 or $7 .^{3}$

OIC was recently added to the Rome IV guidelines under the FBDs category, but it is uniquely distinct in that the etiology is known. It is widely accepted that OIC shares similar characteristics of functional constipation, and in recent years, it has become more prevalent with the rapidly growing health problem of opioid abuse in the United States. Stimulation of opioid receptors throughout the enteric neuronal system affects gastrointestinal function by delaying colonic transit, stimulating non-propulsive motility, and increasing intestinal absorption, thus causing constipation.

\section{Non-prescription treatment options for constipation}

Since the underlying cause of CIC and IBS-C is not fully understood, the treatment strategies often focus on controlling disease symptoms. The first line of treatment for constipation includes recommendations for lifestyle modification, with a focus on dietary change and increasing exercise. ${ }^{6}$ Diets low in fermentable oligosaccharides, disaccharides, monosaccharides, and polyols can reduce some symptoms of IBS, but there is little evidence that this diet can benefit patients with CIC. A large body of evidence supports the use of soluble fiber supplements to alleviate symptoms of both CIC and IBS-C. ${ }^{7,8}$ Fiber alleviates constipation by creating bulky stool that stimulates the peristaltic reflex to increase motility. While fiber provides relief for some patients, it can exacerbate symptoms of constipation such as cramping, bloating, and flatulence. ${ }^{9}$

For patients who are unable to alter lifestyle appropriately and whose diet modifications do not alleviate constipation, the secondary recommendation is non-prescription osmotic and stimulant laxatives. Osmotic laxatives are hypertonic solutions that draw fluid into the intestinal lumen by osmosis to create softer stool. ${ }^{10}$ The most studied osmotic laxative is PEG3350 which has been shown to improve stool frequency and consistency, while also alleviating abdominal pain. ${ }^{11,12}$ Stimulant laxatives, such as Ex-Lax (senna, GlaxoSmithKline, Philadelphia PA) and Dulcolax (bisacodyl, Chattem, Inc., Chattanooga, TN), induce propagated colonic contractions to accelerate colonic transit. ${ }^{13,14}$ Earlier, stimulant laxatives were not routinely prescribed due to reports that senna and bisacodyl could damage the enteric nervous system. However, subsequent studies have discounted that notion, and stimulant laxatives are routinely used as part of a long-term treatment strategy. ${ }^{15,16}$ These non-prescription laxatives only alleviate constipation and do not treat abdominal pain or discomfort which is often associated with CIC and IBS-C.

\section{Prescription treatment options for constipation}

As the cause of OIC is known, peripherally-acting-mu-opioidreceptor-antagonists such as methylnaltrexone and naldemedine have been developed. These drugs are used to treat OIC patients, but have been associated with significant side effects such as abdominal pain and gastroenteritis that have been attributed to opioid withdrawal. ${ }^{17}$ While the etiology of CIC is unknown, there is growing evidence for mis-regulation of serotonin pathways in association with IBS. ${ }^{18}$ This led to the development of $5 \mathrm{HT}$ agonists as potential therapeutic options. The first such drug, Tegaserod (Novartis, Basel, Switzerland), was associated with adverse cardiovascular events and was withdrawn from the market. ${ }^{19}$ Prucalopride (Shire Pharmaceuticals Ltd, London England), was developed as a more specific high-affinity $5 \mathrm{HT}_{4}$ agonist. ${ }^{20-22}$ In clinical trials, Prucalopride had prokinetic gastrointestinal properties and increased the number of spontaneous bowel movements in CIC patients. ${ }^{21-23}$ Although no adverse cardiovascular events have been reported, Prucalopride has significant gastrointestinal side effects including nausea and diarrhea. ${ }^{19}$ While approved for CIC in Europe, concerns about this class of drugs resulting from Tegaserod has 
prevented the Food and Drug Administration (FDA)-approval in the United States. ${ }^{24}$

Intestinal secretagogues are another promising class of drugs to treat constipation. Lubiprostone is a bicyclic fatty acid derived from prostaglandin E1 that activates CLCN2 voltage-gated chloride channels in the intestinal epithelium. ${ }^{25}$ The chloride-rich secretions soften stool, increase intestinal peristalsis, and decrease intestinal transit time. ${ }^{26,27}$ It is FDA approved to treat OIC and CIC in men and women, but IBS-C only in women. ${ }^{27}$ In clinical trials, patients reported increased numbers of bowel movements, improvements in straining, and improvements in stool consistency. ${ }^{28-30}$ The most common side effects of lubiprostone include nausea, headache, and diarrhea, but cardiovascular effects have also been reported. ${ }^{31}$ In summary, there are diverse treatment options for constipation, but none are universally effective for all forms of constipation or in all patients. Moreover, all of the drugs have disruptive side effects such as gastrointestinal complications or severe headaches that reduce patient compliance (Table 1).

\section{Guanylyl cyclase C (GC-C) agonists as secretagogues}

Secretion of solutes and water into the intestinal lumen is essential for lubrication, and dysregulation of solute/fluid balance in the intestine is likely to underlie many cases of diarrhea and constipation. ${ }^{32}$ Cyclic guanosine monophosphate (cGMP) is a second messenger and is a potent regulator of secretion in the intestine. It stimulates chloride secretion by activating type 2 cGMP-dependent protein kinase (PKG2), which in turn phosphorylates the cystic fibrosis transmembrane conductance regulator (CFTR). ${ }^{33,34}$ cGMP directly inhibits the NHE3 $\mathrm{Na}^{+} / \mathrm{H}^{+}$exchanger to reduce sodium reabsorption, and in a CFTR-dependent manner, cGMP also promotes bicarbonate secretion by stimulating $\mathrm{Cl}^{-} / \mathrm{HCO}_{3}^{-}$ exchanger. ${ }^{35,36}$ The effect of increasing cGMP in the intestinal epithelium is a net movement of water into the lumen resulting from solute secretion (Figure 1). The concentration of cGMP in the intestinal epithelium is tightly controlled by the activity of GC-C receptors that convert GTP into cGMP upon stimulation by the endogenous peptide hormones uroguanylin and guanylin. ${ }^{37}$ Activating mutations in the GC-C gene ( GUCY2C) causes a familial diarrhea syndrome, whereas inactivating mutations result in heritable constipation..$^{38,39}$ This genetic evidence underscores the importance of the cGMP signaling axis in FBDs.

The structure and physiological roles of guanylin, uroguanylin, and the heat-stable enterotoxin (STa) that is a molecular mimic of these GC-agonists have been reviewed previously. ${ }^{40}$ Uroguanylin and guanylin exhibit differential expression in the intestinal tract, with the former predominantly in the intestinal villi, and the latter more prominent in the colonic crypt. ${ }^{41}$ In addition, uroguanylin is more active in acidic environments such as in the duodenum, whereas guanylin is more active in alkaline environments. ${ }^{36,42}$ The $\mathrm{pH}$-dependent binding of uroguanylin to $\mathrm{GC}-\mathrm{C}$ confers some degree of autoregulation because the increased $\mathrm{pH}$ resulting from cGMP-dependent inhibition of $\mathrm{H}^{+}$secretion and stimulation of $\mathrm{HCO}_{3}{ }^{-}$exchange

Table I Pharmaceutical agents available for the treatment of constipation

\begin{tabular}{|c|c|c|c|}
\hline Drug name & Mechanism of action & Side effects & Indication \\
\hline $\begin{array}{l}\text { Psyllium (Metamucil), methylcellulose } \\
\text { (Citrucel), calcium polycarbophil } \\
\text { (FiberCon), wheat dextrin (Benefibre) }\end{array}$ & $\begin{array}{l}\text { Bulking agents: indigestible fiber forms a } \\
\text { soft bulky stool to stimulate motility }\end{array}$ & $\begin{array}{l}\text { Bloating, intestinal gas, cramping, } \\
\text { increased constipation }\end{array}$ & CIC, OIC, IBS-C \\
\hline $\begin{array}{l}\text { PEG3350, } \\
\text { lactulose, sorbitol } \\
\text { magnesium salts } \\
\text { (milk of magnesia) }\end{array}$ & $\begin{array}{l}\text { Osmotic laxatives: draw water into the } \\
\text { bowel from the intestinal lumen and } \\
\text { soften the stool }\end{array}$ & $\begin{array}{l}\text { Electrolyte imbalance, leading to } \\
\text { increased thirst and dehydration, nausea, } \\
\text { diarrhea }\end{array}$ & $\begin{array}{l}\text { Occasional } \\
\text { constipation }\end{array}$ \\
\hline $\begin{array}{l}\text { Senna (Senokot) } \\
\text { Bisacodyl (Ex-Lax, Dulcolax) }\end{array}$ & $\begin{array}{l}\text { Stimulant laxatives: induce propagated } \\
\text { colonic contractions to accelerate transit; } \\
\text { increase intestinal fluid accumulation and } \\
\text { laxation by altering water and electrolyte } \\
\text { secretion }\end{array}$ & $\begin{array}{l}\text { Abdominal pain or cramping, vomiting, } \\
\text { electrolyte imbalance with extended use }\end{array}$ & $\begin{array}{l}\text { Occasional } \\
\text { constipation }\end{array}$ \\
\hline Lubiprostone (Amitiza) & $\begin{array}{l}\text { Secretagogue: activates CIC- } 2 \text { chloride } \\
\text { channels to increase secretion }\end{array}$ & $\begin{array}{l}\text { Nausea (30\%), diarrhea and headache } \\
\text { (I3\%), abdominal pain, post market } \\
\text { reports of tachycardia, syncope and } \\
\text { hypotension }\end{array}$ & CIC, OIC, IBS-C \\
\hline Prucalopride & $\begin{array}{l}\text { Prokinetics: high affinity serotonin } 4 \\
\text { receptor agonist }\end{array}$ & $\begin{array}{l}\text { Not approved in the USA due to } \\
\text { ischemic events; other side effects } \\
\text { include nausea (I } 17 \%) \text {, diarrhea (12.1\%), } \\
\text { abdominal pain }\end{array}$ & $\mathrm{CIC}$ \\
\hline
\end{tabular}

Abbreviations: $\mathrm{CIC}$, chronic idiopathic constipation; OIC, opioid-induced constipation; IBS-C, irritable bowel syndrome with constipation. 


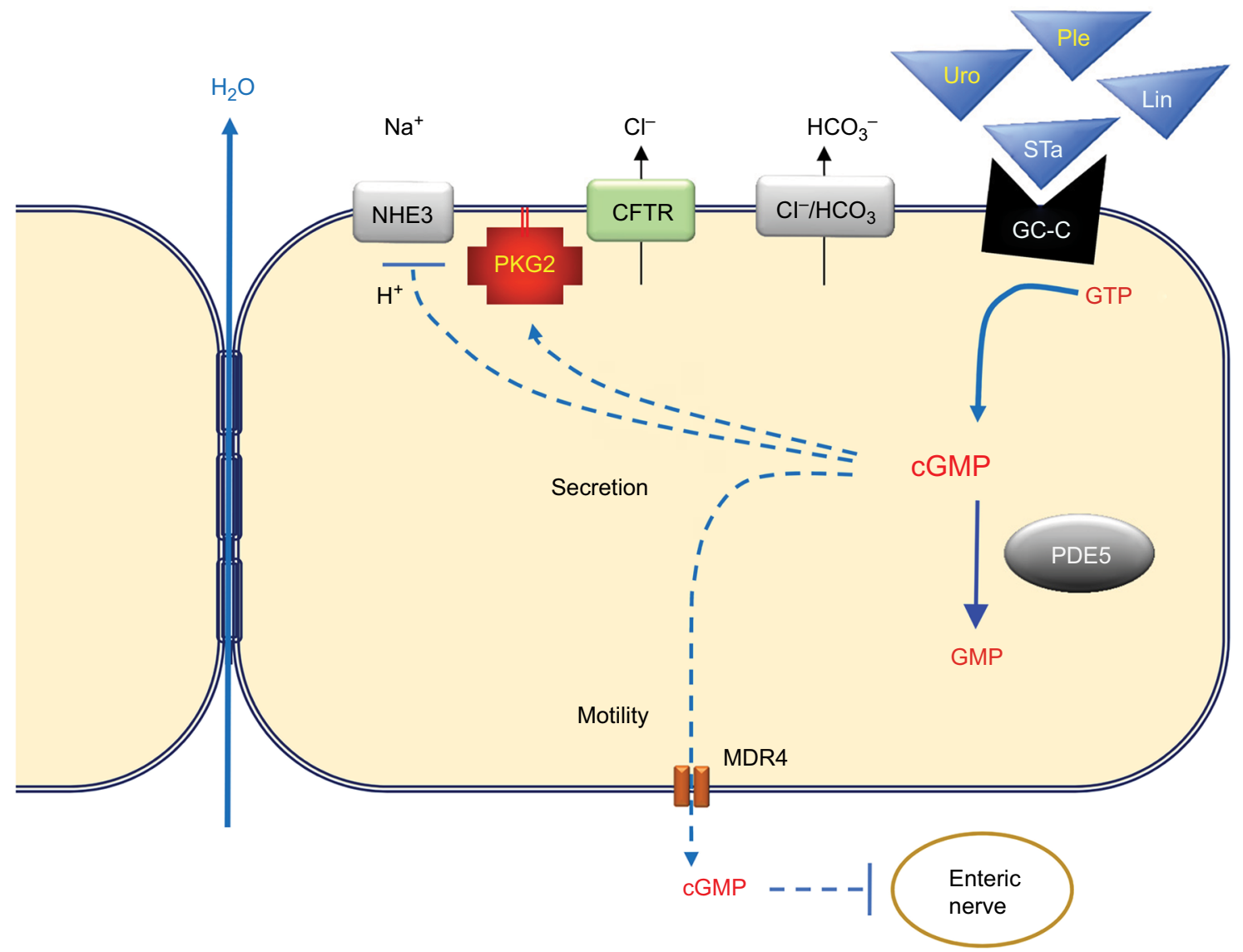

Figure I The cyclic guanosine monophosphate (cGMP) signaling axis in the intestinal epithelium. Guanylyl cyclase C (GC-C) receptors expressed on the apical surface of intestinal epithelial cells produce cGMP from guanosine triphosphate (GTP) when bound by endogenous hormones uroguanylin (Uro) and guanylin (Gn). The synthetic peptide agonist plecanatide (Ple) mimics Uro, whereas linaclotide (Lin) mimics the heat-stable toxin from enterotoxigenic bacteria (STa). Elevated cGMP levels increase luminal solutes by blocking $\mathrm{Na}^{+}$uptake through the sodium-hydrogen exchanger (NHE), and by activating type 2 cGMP-dependent protein kinase (PKG2), which in turn activates the cystic fibrosis transmembrane conductance regulator (CFTR). Several mechanisms restore equilibrium, including cGMP-specific phosphodiesterase 5 (PDE5) that hydrolyzes cGMP to inactive GMP, and by export of cGMP by multidrug resistance protein 4 (MDR4). Blockade of $\mathrm{H}^{+}$exchange and secretion of $\mathrm{HCO}_{3}^{-}$by the chloridebicarbonate exchanger $\left(\mathrm{Cl}^{-} / \mathrm{HCO} 3\right)$ increases luminal $\mathrm{pH}$ and reduces affinity of uroguanylin and plecanatide for $\mathrm{GC}-\mathrm{C}$ (but not guanylin, linaclotide, or $\mathrm{STa}$ ). Taken together, the stimulation of GC-C results in water secretion and reduced enteric nociception.

antagonizes uroguanylin efficacy. STa enterotoxin differs from uroguanylin in the amino-terminal residues than confer $\mathrm{pH}-$ dependent binding, resulting in excessive secretion and diarrhea. Based upon the secretagogue effect of GC-C agonists, synthetic peptides mimicking uroguanylin (plecanatide) and STa (linaclotide) have been developed for the treatment of constipation. Linaclotide was the first GC-C agonist approved and is closer in sequence to STa; with more potent GC-C activity that is less sensitive to $\mathrm{pH} .{ }^{43}$ Plecanatide was modeled after uroguanylin except for an amino-terminal substitution of one $\mathrm{pH}$ sensing residue. Plecanatide therefore retains some $\mathrm{pH}$ sensitivity, but is more potent than uroguanylin. ${ }^{44}$

\section{Clinical efficacy of plecanatide and linaclotide GC-C agonists}

In August 2012, linaclotide was approved for treatment of adult patients with IBS-C (290 $\mu \mathrm{g})$ and CIC $(145 \mu \mathrm{g})$. More recently, $72 \mu \mathrm{g}$ was also approved in order to help physicians better treat the heterogeneous population of adult patients suffering from CIC. In January 2017, another intestinal secretagogue and GC-C agonist plecanatide was approved for CIC (3 mg), and within a year, it was also approved for IBS-C at the same $3 \mathrm{mg}$ dose. Plecanatide is administered orally in a water-soluble tablet and its mechanism of action is on the luminal epithelium, with minimal absorption and systemic availability. ${ }^{44}$

Two 12-week clinical studies were conducted to determine the efficacy of plecanatide for the treatment of symptoms of CIC.$^{45}$ These were double-blind, placebo-controlled, randomized, multi-center trials including about 2000 adult patients. Patients were required to meet modified Rome III criteria for CIC for at least 3 months prior to the study, with symptoms being present for at least 6 months prior to diagnosis. These modified criteria included patients reporting 
less than three bowel movements per week, rarely reporting loose stool without the use of laxatives, and the patients could not meet the criteria for IBS-C. In addition, patients were required to report at least two of the following symptoms in at least $25 \%$ of defecations: straining, lumpy or hard stool, sensation of incomplete evacuations, or sensation of anorectal obstruction or blockage.

Patients self-reported daily spontaneous bowel movements (SBM) defined as a bowel movement that occurs without the use of laxatives. They were also instructed to record complete spontaneous bowel movements (CSBM) which are SBMs that give the patients a sense of complete evacuation. The primary efficacy endpoint of this study was the percentage of patients who were CSBM responders over the 12-week period. A CSBM responder was defined as a patient who had more than three CSBMs in a week. Plecanatide exhibited a rapid onset of efficacy, increasing the frequency of CSBMs, often as early as 1 week of treatment. Both the doses of plecanatide used in the study ( 3 and $6 \mathrm{mg}$ ) resulted in a greater percentage of overall CSBM responders than placebo. Throughout the treatment period, improvements were also observed in stool frequency and consistency and straining during bowel movements. During a 2-week followup period with no drug treatment, CSBMs of patients who had received plecanatide returned to placebo group. The results of the Phase III trial for plecanatide were nearly identical to the earlier clinical trial of linaclotide, ${ }^{46}$ including similar diagnostic criteria, exclusion criteria, and primary endpoints.
Linaclotide and plecanatide both had around a $20 \%$ response rate at all doses, and both the drugs significantly improved secondary endpoints such as stool consistency and frequency, severity of straining, and abdominal discomfort (Table 2).

The most notable difference between the clinical trials was that patients taking linaclotide reported incidence of diarrhea three times higher than patients taking plecanatide $(16 \%$ vs $6 \%$, respectively) (Table 2 ). A reasonable explanation for this observation is that plecanatide retains $\mathrm{pH}$ sensitivity and is therefore subject to autoregulation, in contrast to linaclotide which was modeled after the diarrhea-causing STa enterotoxin. However, differences in the method of reporting adverse events might also account for the differences, since the definition of an adverse event was more stringent in the plecanatide trials. Although there have been no head-to-head comparisons of the effects of linaclotide and plecanatide in either IBS-C and CIC, a recent meta-analysis of the efficacy and tolerability of both GC-C agonists concluded that the treatment effects of each drug relative to placebo were comparable and that there was no significant difference in the odds of diarrhea for either drug. ${ }^{47}$

\section{Conclusion and future directions}

Despite the plethora of potential underlying causes of CIC, patient responsiveness to plecanatide and linaclotide was similar in the independent Phase III studies. A reasonable explanation is that deficiency in the expression of endogenous $\mathrm{GC}-\mathrm{C}$ agonists or in the $\mathrm{GC}-\mathrm{C}$ receptor was the underlying

Table 2 GC-C agonist clinical trial data for chronic idiopathic constipation

\begin{tabular}{|c|c|c|c|c|}
\hline Drug & Study design & Demographics/study size & Efficacy & Adverse effects \\
\hline Linaclotide & $\begin{array}{l}2 \text { randomized, I2-week, } \\
\text { multicenter, double-blind, } \\
\text { placebo-controlled, dual-dose } \\
\text { trials } \\
\text { Once daily linaclotide } 145 \mu g \text {, } \\
290 \mu g \text {, or placebo pill } \\
\text { Administered } 30 \text { min prior to } \\
\text { breakfast }\end{array}$ & 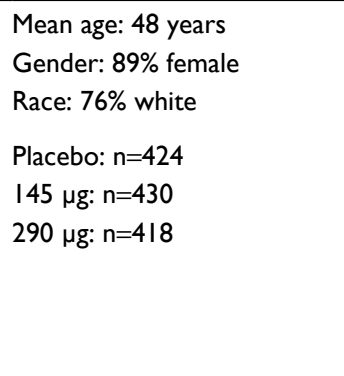 & 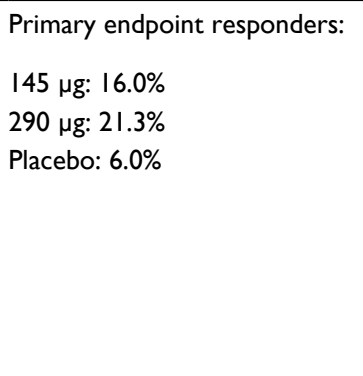 & 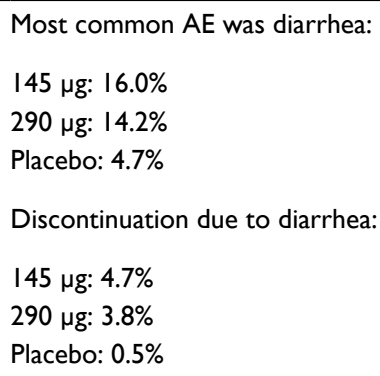 \\
\hline Plecanatide & $\begin{array}{l}\text { Randomized, I2-week, } \\
\text { multicenter, double-blind, } \\
\text { placebo-controlled, dual-dose } \\
\text { trial } \\
\text { Once daily plecanatide } 3 \mathrm{mg}, 6 \\
\mathrm{mg} \text {, or placebo pill } \\
\text { Instructed to take with or } \\
\text { without food }\end{array}$ & $\begin{array}{l}\text { Mean age: } 45 \text { years } \\
\text { Gender: } 80 \% \text { female } \\
\text { Race: } 70 \% \text { white } \\
\text { Placebo: } n=454 \\
3 \text { mg: } n=453 \\
6 \text { mg: } n=441\end{array}$ & $\begin{array}{l}\text { Primary endpoint responders: } \\
3 \mathrm{mg}: 21.0 \% \\
6 \mathrm{mg}: 19.5 \% \\
\text { Placebo: } 10.2 \%\end{array}$ & $\begin{array}{l}\text { Most common AE was diarrhea: } \\
3 \mathrm{mg}: 5.9 \% \\
6 \mathrm{mg}: 5.7 \% \\
\text { Placebo: } 1.3 \% \\
\text { Discontinuation due to diarrhea: } \\
3 \mathrm{mg}: 2.7 \% \\
6 \mathrm{mg}: 2.6 \% \\
\text { Placebo: } 0.4 \%\end{array}$ \\
\hline
\end{tabular}

Abbreviations: GC-C, guanylyl cyclase C; AE, adverse event. 
cause of constipation in the responding patients and that treatment was essentially "hormone replacement therapy." Although differences in relative severity were noted, the incidence of diarrhea was also similar for each drug (as a function of placebo). Both linaclotide and plecanatide have clear warnings against using either drug in pediatric patients because it can result in severe dehydrating diarrhea. The cause of this has been suggested (in the prescribing information for linaclotide) to involve overexpression of GC-C in the pediatric intestine relative to the adult. It is therefore plausible that the subset of patients who responded to the GC-C agonists with severe diarrhea might also express higher levels of GC-C (eg, a pediatric gut). This concept highlights the notion that the relative expression of all cGMP signaling components is important, and imbalances could cause either constipation or diarrhea. The cGMP phosphodiesterase (eg, PDE5) is expressed in the intestinal epithelium and is likely to play an essential role in antagonizing the effects of GC-C agonists. ${ }^{48,49}$ It is therefore possible that overexpression of PDE5 could be an underlying cause of constipation in some patients. Such patients would likely be refractory to linaclotide and plecanatide, but might be treated with PDE5 inhibitors. It is important to note that diarrhea is not a common side effect of PDE5 inhibitors at levels prescribed for erectile dysfunction. A likely explanation is that PDE5 inhibitors amplify endogenous cGMP levels that are generated when the GC-C agonists are released. The increased cGMP level resulting from PDE5 inhibition would therefore be subject to the same autoregulatory circuit described above for uroguanylin. A recent study has shown that PDE5 inhibition is as effective at correcting constipation as linaclotide in preclinical mouse models, suggesting that these drugs might also be clinically relevant for treating FBDs. ${ }^{50}$

Although the impetus for developing synthetic GC-C agonists was the established role of the endogenous hormones in secretion, novel preclinical and clinical observations suggest that their therapeutic potential extends well beyond constipation. Both linaclotide and plecanatide (more recently) are also FDA-approved to treat constipation associated with IBS-C. The clinical response in this cohort was similar to CIC patients, but an unexpected analgesic effect was reported that was ostensibly independent of fluid secretion. ${ }^{47,51}$ While the underlying mechanism is poorly understood, preclinical evidence suggests that secreted epithelial cGMP has a dampening effect on neural afferents in the lamina propria. ${ }^{52-54}$ Increasing cGMP in the intestinal epithelium has also been shown by extensive preclinical studies to suppress intestinal carcinogenesis ${ }^{5-58}$ and promote barrier function in the colon. ${ }^{59-61}$ These intriguing findings underscore the clinical potential of GC-C agonists for treating post-infectious IBS, ulcerative colitis, and for chemoprevention of colorectal cancer. ${ }^{61-63}$ Although this may be counterintuitive, a drug formulation designed for delivery to the colon might avoid the intestinal secretagogue effect while maintaining barrier support and/or neuromuscular benefit.

\section{Acknowledgment}

This work was supported by the National Cancer Institute grant no. CA17262701A1.

\section{Disclosure}

The authors report no conflicts of interest in this work.

\section{References}

1. Pinto Sanchez MI, Bercik P. Epidemiology and burden of chronic constipation. Can J Gastroenterol. 2011;25:11B-15B.

2. Camilleri M, Ford AC, Mawe GM, et al. Chronic constipation. Nat Rev Dis Primers. 2017;3:17095.

3. Mearin F, Lacy BE, Chang L, et al. Bowel disorders. Gastroenterology. Epub 2016 Feb 18.

4. Drossman DA. Functional gastrointestinal disorders: history, pathophysiology, clinical features, and Rome IV. Gastroenterology. 2016;150:1262-1279.e1262.

5. Schmulson MJ, Drossman DA. What is new in Rome IV. J Neurogastroenterol Moti. 2017;23:151-163.

6. Chang L, Lembo A, Sultan S. American Gastroenterological Association Institute Technical Review on the pharmacological management of irritable bowel syndrome. Gastroenterology. 2014;147:1149-1172. e1142.

7. Eswaran S, Muir J, Chey WD. Fiber and functional gastrointestinal disorders. Am J Gastroenterol. 2013;108:718-727.

8. McRorie JW, Daggy BP, Morel JG, Diersing PS, Miner PB, Robinson M. Psyllium is superior to docusate sodium for treatment of chronic constipation. Aliment Pharmacol Ther. 1998;12:491-497.

9. Rao SS, Rattanakovit K, Patcharatrakul T. Diagnosis and management of chronic constipation in adults. Nat Rev Gastroenterol Hepatol. 2016;13:295-305.

10. Ford AC, Suares NC. Effect of laxatives and pharmacological therapies in chronic idiopathic constipation: systematic review and meta-analysis. Gut. 2011;60:209-218.

11. DiPalma JA, DeRidder PH, Orlando RC, Kolts BE, Cleveland MB. A randomized, placebo-controlled, multicenter study of the safety and efficacy of a new polyethylene glycol laxative. Am J Gastroenterol. 2000;95:446-450.

12. Dipalma JA, Cleveland MV, McGowan J, Herrera JL. A randomized, multicenter, placebo-controlled trial of polyethylene glycol laxative for chronic treatment of chronic constipation. Am J Gastroenterol. 2007;102:1436-1441.

13. Pare P, Fedorak RN. Systematic review of stimulant and nonstimulant laxatives for the treatment of functional constipation. Can J Gastroenterol Hepatol. 2014;28:549-557.

14. Mueller-Lissner S, Kamm MA, Wald A, et al. Multicenter, 4-week, double-blind, randomized, placebo-controlled trial of sodium picosulfate in patients with chronic constipation. Am J Gastroenterol. 2010;105(4):897-903.

15. Kamm MA, Mueller-Lissner S, Wald A, Richter E, Swallow R, Gessener U. Oral bisacodyl is effective and well-tolerated in patients with chronic constipation. Clin Gastroenterol Hepatol. 2011;9:577-583. 
16. Kiernan JA, Heinicke EA. Sennosides do not kill myenteric neurons in the colon of the rat or mouse. Neuroscience. 1989;30:837-842.

17. Camilleri M, Lembo A, Katzka DA. Opioids in gastroenterology: treating adverse effects and creating therapeutic benefits. Clin Gastroenterol Hepatol. 2017;15:1338-1349.

18. Coss-Adame E, Rao SS. Brain and gut interactions in irritable bowel syndrome: new paradigms and new understandings. Curr Gastroenterol Rep. 2014;16:379.

19. Shin A, Camilleri M, Kolar G, Erwin P, West CP, Murad MH. Systematic review with meta-analysis: highly selective 5-HT4 agonists (prucalopride, velusetrag or naronapride) in chronic constipation. Aliment Pharmacol Ther. 2014;39:239-253.

20. Miner PB Jr, Camilleri M, Burton D, et al. Prucalopride induces high-amplitude propagating contractions in the colon of patients with chronic constipation: a randomized study. Neurogastroenterol Motil. 2016;28:1341-1348

21. Camilleri M, Piessevaux H, Yiannakou Y, et al. Efficacy and safety of prucalopride in chronic constipation: an integrated analysis of six randomized, controlled clinical trials. Dig Dis Sci. 2016;61:2357-2372.

22. Emmanuel A, Cools M, Vandeplassche L, Kerstens R. Prucalopride improves bowel function and colonic transit time in patients with chronic constipation: an integrated analysis. Am J Gastroenterol. 2014;109: 887-894.

23. Tack J, Stanghellini V, Dubois D, Joseph A, Vandeplassche L, Kerstens R. Effect of prucalopride on symptoms of chronic constipation. Neurogastroenterol Motil. 2014;26:21-27.

24. Layer P, Keller J, Loeffler H, Kreiss A. Tegaserod in the treatment of irritable bowel syndrome (IBS) with constipation as the prime symptom Ther Clin Risk Manag. 2007;3:107-118.

25. Li F, Fu T, Tong WD, et al. Lubiprostone is effective in the treatment of chronic idiopathic constipation and irritable bowel syndrome: a systematic review and meta-analysis of randomized controlled trials. Mayo Clin Proc. 2016;91:456-468.

26. Camilleri M, Bharucha AE, Ueno R, et al. Effect of a selective chloride channel activator, lubiprostone, on gastrointestinal transit, gastric sensory, and motor functions in healthy volunteers. Am J Physiol Gastrointest Liver Physiol. 2006;290:G942-G947.

27. Wilson N, Schey R. Lubiprostone in constipation: clinical evidence and place in therapy. Ther Adv Chronic Dis. 2015;6:40-50.

28. Jamal MM, Adams AB, Jansen JP, Webster LR. A randomized, placebocontrolled trial of lubiprostone for opioid-induced constipation in chronic noncancer pain. Am J Gastroenterol. 2015;110:725-732.

29. Cryer B, Katz S, Vallejo R, Popescu A, Ueno R. A randomized study of lubiprostone for opioid-induced constipation in patients with chronic noncancer pain. Pain Med. 2014;15:1825-1834.

30. Barish CF, Drossman D, Johanson JF, Ueno R. Efficacy and safety of lubiprostone in patients with chronic constipation. Dig Dis Sci. 2010;55:1090-1097.

31. Amitiza [package insert]. Takeda Pharmaceuticals America Inc. Deerfield, IL 60015; 2017.

32. Field M. Intestinal ion transport and the pathophysiology of diarrhea. J Clin Invest. 2003;111:931-943.

33. Pfeifer A, Aszódi A, Seidler U, Ruth P, Hofmann F, Fässler R. Intestinal secretory defects and dwarfism in mice lacking cGMP-dependent protein kinase II. Science. 1996;274:2082-2086.

34. Vaandrager AB, Bot AG, Ruth P, et al. Differential role of cyclic GMPdependent protein kinase II in ion transport in murine small intestine and colon. Gastroenterology. 2000;118:108-114.

35. Cha B, Kim JH, Hut H, et al. cGMP inhibition of $\mathrm{Na}+\mathrm{H}+$ antiporter 3 (NHE3) requires PDZ domain adapter NHERF2, a broad specificity protein kinase G-anchoring protein. J Biol Chem. 2005;280:16642-16650.

36. Joo NS, London RM, Kim HD, Forte LR, Clarke LL. Regulation of intestinal $\mathrm{Cl}-$ and $\mathrm{HCO}$-secretion by uroguanylin. Am J Physiol. 1998;274:G633-G644.

37. Vaandrager AB. Structure and function of the heat-stable enterotoxin receptor/guanylyl cyclase C. Mol Cell Biochem. 2002;230:73-83.
38. Fiskerstrand T, Arshad N, Haukanes BI, et al. Familial diarrhea syndrome caused by an activating GUCY2C mutation. $N$ Engl $J$ Med. 2012;366:1586-1595.

39. Romi H, Cohen I, Landau D, et al. Meconium ileus caused by mutations in GUCY2C, encoding the CFTR-activating guanylate cyclase 2C. $\mathrm{Am}$ J Hum Genet. 2012;90:893-899

40. Forte LR Jr. Uroguanylin and guanylin peptides: pharmacology and experimental therapeutics. Pharmacol Ther. 2004;104:137-162.

41. Whitaker TL, Witte DP, Scott MC, Cohen MB. Uroguanylin and guanylin: distinct but overlapping patterns of messenger RNA expression in mouse intestine. Gastroenterology. 1997;113:1000-1006.

42. Hamra FK, Eber SL, Chin DT, Currie MG, Forte LR. Regulation of intestinal uroguanylin/guanylin receptor-mediated responses by mucosal acidity. Proc Natl Acad Sci U SA. 1997;94:2705-2710).

43. Bryant AP, Busby RW, Bartolini WP, et al. Linaclotide is a potent and selective guanylate cyclase $\mathrm{C}$ agonist that elicits pharmacological effects locally in the gastrointestinal tract. Life Sci. 2010;86:760-765.

44. Shailubhai K, Comiskey S, Foss JA, et al. Plecanatide, an oral guanylate cyclase $\mathrm{C}$ agonist acting locally in the gastrointestinal tract, is safe and well-tolerated in single doses. Dig Dis Sci. 2013;58:2580-2586.

45. Miner PB Jr, Koltun WD, Wiener GJ, et al. A randomized phase III clinical trial of plecanatide, a uroguanylin analog, in patients with chronic idiopathic constipation. Am J Gastroenterol. 2017;112:613-621.

46. Lembo AJ, Schneier HA, Shiff SJ, et al. Two randomized trials of linaclotide for chronic constipation. N Engl J Med. 2011;365: $527-536$.

47. Shah ED, Kim HM, Schoenfeld P. Efficacy and tolerability of guanylate cyclase-C agonists for irritable bowel syndrome with constipation and chronic idiopathic constipation: a systematic review and meta-analysis. Am J Gastroenterol. 2018;113:329-338.

48. Bakre MM, Sopory S, Visweswariah SS. Expression and regulation of the cGMP-binding, cGMP-specific phosphodiesterase (PDE5) in human colonic epithelial cells: role in the induction of cellular refractoriness to the heat-stable enterotoxin peptide. J Cell Biochem. 2000;77:159-167.

49. Sopory S, Kaur T, Visweswariah SS. The cGMP-binding, cGMP-specific phosphodiesterase (PDE5): intestinal cell expression, regulation and role in fluid secretion. Cell Signal. 2004;16:681-692.

50. Sharman SK, Islam BN, Hou Y, et al. Sildenafil normalizes bowel transit in preclinical models of constipation. PLoS One. 2017;12:e176673.

51. Rao SS, Quigley EM, Shiff SJ, et al. Effect of linaclotide on severe abdominal symptoms in patients with irritable bowel syndrome with constipation. Clin Gastroenterol Hepatol. 2014;12:616-623.

52. Castro J, Harrington AM, Hughes PA, et al. Linaclotide inhibits colonic nociceptors and relieves abdominal pain via guanylate cyclase-C and extracellular cyclic guanosine 3',5'-monophosphate. Gastroenterology. 2013;145(6):1334-1346.e1-11.

53. Eutamene H, Bradesi S, Larauche M, et al. Guanylate cyclase C-mediated antinociceptive effects of linaclotide in rodent models of visceral pain. Neurogastroenterol Motil. 2010;22:e312-e384.

54. Feng B, Kiyatkin ME, La JH, et al. Activation of guanylate cyclase-C attenuates stretch responses and sensitization of mouse colorectal afferents. J Neurosci. 2013;33:9831-9839.

55. Chang WL, Masih S, Thadi A, et al. Plecanatide-mediated activation of guanylate cyclase-C suppresses inflammation-induced colorectal carcinogenesis in Apc+/Min-FCCC mice. World J Gastrointest Pharmacol Ther. 2017;8:47-59.

56. Islam BN, Sharman SK, Hou Y, et al. Sildenafil suppresses inflammation-driven colorectal cancer in mice. Cancer Prev Res (Phila). 2017; 10:377-388.

57. Shailubhai K, Yu HH, Karunanandaa K, et al. Uroguanylin treatment suppresses polyp formation in the $\mathrm{Apc}(\mathrm{Min} /+)$ mouse and induces apoptosis in human colon adenocarcinoma cells via cyclic GMP. Cancer Res. 2000;60:5151-5157.

58. Sharman SK, Islam BN, Hou Y, et al. Cyclic-GMP-elevating agents suppress polyposis in Apc(Min) mice by targeting the preneoplastic epithelium. Cancer Prev Res (Phila). 2018;11:81-92. 
59. Han X, Mann E, Gilbert S, et al. Loss of guanylyl cyclase C (GCC) signaling leads to dysfunctional intestinal barrier. PLoS One. 2011;6:e16139.

60. Lin JE, Snook AE, Li P, et al. GUCY2C opposes systemic genotoxic tumorigenesis by regulating AKT-dependent intestinal barrier integrity. PLoS One. 2012; 7:e31686

61. Mann EA, Harmel-Laws E, Cohen MB, Steinbrecher KA. Guanylate cyclase $\mathrm{C}$ limits systemic dissemination of a murine enteric pathogen. BMC Gastroenterol. 2013;13:135.
62. Shailubhai, K, Vaseem P, Krishna Priya A, et al. Plecanatide and dolcanatide, novel guanylate cyclase-C agonists, ameliorate gastrointestinal inflammation in experimental models of murine colitis. World $J$ Gastrointest Pharmacol Ther. 2015;6:213-222.

63. Wang R, Kwon IK, Singh N, et al. Type 2 cGMP-dependent protein kinase regulates homeostasis by blocking c-Jun N-terminal kinase in the colon epithelium. Cell Death Differ. 2014;21:427-437.

\section{Publish your work in this journal}

The International Journal of General Medicine is an international, peer-reviewed open-access journal that focuses on general and internal medicine, pathogenesis, epidemiology, diagnosis, monitoring and treatment protocols. The journal is characterized by the rapid reporting of reviews, original research and clinical studies across all disease areas.
The manuscript management system is completely online and includes a very quick and fair peer-review system, which is all easy to use. Visit http://www.dovepress.com/testimonials.php to read real quotes from published authors.

Submit your manuscript here: https://www.dovepress.com/international-journal-of-general-medicine-journal 